\title{
Razvoj depresivnosti kod onkoloških bolesnika
}

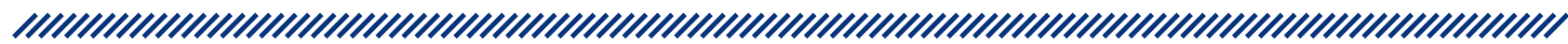

\author{
1 Marina Cigić \\ 2 Josipa Rožman \\ 1 Interni odjel-Dnevna bolnica onkologije, Opća bolnica \\ Šibenik \\ 2 Odjel za psihijatriju, Opća bolnica Karlovac
}

\section{Sažetak}

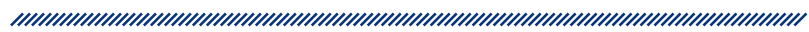

Depresija je najčešći psihijatrijski poremećaj koji je u ukupnoj populaciji prema učestalosti na četvrtom mjestu. Osobe koje se suočavaju sa smrću prolaze kroz različita duševna stanja i faze, kao što su gnjev, cjenkanje, depresija i prihvaćanje, a najčešće su obrane kojima se onkološki bolesnik koristi regresija, poricanje, projekcija i potiskivanje. Istraživanja su pokazala kako su psihijatrijski poremećaji učestali podjednako, ako ne i više od ostalih tjelesnih simptoma kod onkoloških bolesnika.

Cilj ovog rada bio je procijeniti kliničku sliku depresije kod onkoloških bolesnika na temelju upitnika za test depresije (Beck Depression Inventory). Istraživanje je provedeno na internom odjelu Opće bolnice Šibenik u onkološkoj ambulanti na uzorku od 50 ispitanika.

Rezultati istraživanja pokazali su kako među ispitanicima nije utvrđen teški oblik depresije te kako je u postotku u kojem se pojavila, prema testu BDI, u blagom razvoju.
Ključne riječi: depresija, onkološki bolesnici, BDI

Datum primitka: 30.09.2020.

Datum prihvaćanja: 15.01.2021.

https://doi.org/10.24141/1/7/1/2

Adresa za dopisivanje:

Josipa Rožman

A: Bridići 5, Karlovac

E-pošta: petrunic.josipa@gmail.com

T: +38595 8019871 


\section{Uvod}

Jedan od najvećih javnozdravstvenih problema u svijetu i drugi najčešći uzrok smrti, čija incidencija raste zbog ubrzanog starenja stanovništva i izlaganja brojnim rizičnim faktorima, upravo je karcinom. Razna suvremena istraživanja dokazala su kako otprilike polovina onkoloških bolesnika ima i razne psihijatrijske poremećaje koji zahtijevaju pravilnu dijagnostiku i liječenje. Od 50-ih godina prošlog stoljeća razvija se psihoonkologija, kao posebna disciplina koja istražuje psihičke faktore u okvirima multidimenzionalnoga razumijevanja malignih oboljenja te uključuje dijagnostičke, terapijske, edukativne $\mathrm{i}$ istraživačke aktivnosti psihijatra u onkološkim institucijama. ${ }^{1}$

Već kod prvog susreta s malignom bolešću u ljudima se bude intenzivne emocionalne reakcije od kojih je najčešći strah. Prirodno se javlja strah od smrti, odnosno odvajanja od drugih i samoga sebe, koji često izazivaju teška anksiozna stanja kod bolesnika sve do razmjera panike, a značajne su psihološke reakcije koje se javljaju kod ovih bolesnika depresivnost, manija i psihotične reakcije. Osobe koje se suočavaju sa smrću prolaze kroz različita duševna stanja i faze, kao što su gnjev, cjenkanje, depresija i prihvaćanje, a najčešće su obrane kojima se onkološki bolesnik koristi regresija, poricanje, projekcija i potiskivanje. ${ }^{2}$ Istraživanja su pokazala kako su psihijatrijski poremećaji učestali podjednako, ako ne i više od ostalih tjelesnih simptoma kod onkoloških bolesnika. Psihijatrijski problemi s kojima se susreću onkološki bolesnici jesu anksiozni i depresivni poremećaji, poremećaji prilagodbe, delirij i drugi kognitivni poremećaji te su kod ovakvih poremećaja učestali i drugi problemi poput suicidalnih ideja, posljedica nedostatka obiteljske i socijalne podrške, pitanje sposobnosti donošenja odluka te žalovanje. ${ }^{3}$ Unatoč tomu što su se danas razvile nove dijagnostičke i terapijske procedure u liječenju onkoloških bolesnika, maligne bolesti i dalje su izvor straha za bolesnika, jer su usko povezane s dugotrajnim i neizdrživim bolovima. ${ }^{1}$ Bol je kod onkoloških bolesnika složen pojam koji zahvaća cijelu bolesnikovu osobnost $\mathrm{s}$ tjelesnim, kognitivnim, socijalnim i duhovnim dimenzijama. Brojna istraživanja $i$ iskustvo u liječenju pokazuju da je bol znatno intenzivnija i učestalija kod onkoloških bolesnika sa psihijatrijskim komorbiditetom. ${ }^{1} \mathrm{U}$ liječenju onkoloških bolesnika uvijek je važan multidisciplinarni pristup liječenju, aktivno sudjelovanje bolesnika i stalna komunikacija među članovima tima. Psihijatri su tako, u nekim specijaliziranim onkološkim centrima, integrirani dio onkološkog tima, koji uz detaljnu procjenu bolesnika primjenjuju psihoterapijske, farmakoterapijske i socioterapijske intervencije te imaju važnu ulogu u rješavanju socijalnih, duhovnih, pravnih i etičkih pitanja koji ponekad kompliciraju skrb za karcinomske bolesnike. ${ }^{2}$ Emocionalna podrška i empatija medicinskog osoblja izrazito su važne tijekom svih faza liječenja bolesnika, jer u pravilu bolesnici vole iskren i otvoren odnos liječnika kojemu mogu vjerovati. $U$ onkologiji je posebno važan i koncept informiranog pristanka, pa tako brojni onkološki centri u svijetu imaju psihoonkološka savjetovališta, u kojima rade osobe educirane u vještinama komunikacije te znaju prepoznati psihološke smetnje kod bolesnika.

Psihoterapijske intervencije pokazale su se izrazito korisnima u liječenju onkoloških bolesnika, a razlikuju se sljedeće intervencije:

1. suportivne - individualne, grupne, partnerske, obiteljske

2. psihoedukacija

3. tehnike relaksacije

4. mogućnost rada bolesnika na emocionalnim, socijalnim, bračnim i drugim pitanjima. ${ }^{4}$

Psihijatar bi tijekom liječenja trebao utjecati na poboljšanje samopoštovanja i povjerenja bolesnika uz postupno razvijanje njegova osjećaja ljubavi i prihvaćenosti. Psihoterapija je iznimno korisna u svim fazama bolesti, a suportivne, kognitivne i relaksacijske metode smanjuju bol. Zadatak je liječnika onkologa, ali i suradnog psihijatra, unaprijediti kvalitetu života bolesnika nakon dijagnosticiranja bolesti, poboljšati suradnju i toleranciju na terapijski tretman te umanjiti mogućnost psihijatrijskih komplikacija kod bolesnika. Unatoč činjenici da dijagnostika onkoloških bolesti kod bolesnika vrlo često dovodi do posljedičnih psihijatrijskih poremećaja, ovim se poremećajima često pridaje premalo važnosti u liječenju onkoloških bolesnika pa često dolazi do neadekvatnog liječenja i velike subjektivne patnje bolesnika. Najvažnija je interakcija između zdravstvenih djelatnika koji rade s bolesnicima i njihovim obiteljima, jer na vrijeme otkriven psihijatrijski poremećaj neće napraviti velike posljedice na liječenje onkološkog bolesnika.

\section{Psihosocijalni aspekti onkoloških bolesti}

Teorije o psihosomatskom podrijetlu malignih bolesti dijele se na dvije skupine:

- permisivne - umjerenije i pretpostavljaju da psihogeni čimbenici ne djeluju direktno kancerogeno, već da drugi uzročnici omogućavaju pojavnost malignih alternacija 
- kauzalne - nesvjesni konflikti svoj izraz nalaze na tjelesnom planu, gdje se zbog nekontroliranog rasta stanice upotrebljava i izraz shizofrenija na somatskom planu; zbog realnog gubitka objekta na tjelesnom planu nesvjesnim bujanjem novoga tkiva simbolički se ponovno stvara izgubljeni objekt. ${ }^{5}$

U teorijskim objašnjenjima pojave malignih bolesti važnu ulogu ima teorija stresa, jer pod utjecajem stresa dolazi do slabljenja obrambenih sustava organizma, najčešće endokrinološkog i imunosnog. Pritom nije važan samo intenzitet stresa, već i sposobnost određene osobe da se, ovisno o svojim psihofizičkim mogućnostima, obrani od stresa.

Istraživanja Kiecolt-Glasera dokazala su da je psihološki stres direktno povezan s imunosnim odgovorom, jer se smanjuje broj receptora, što je posljedično povezano sa slabijim oporavkom DNA-a koji se pritom oštećuje te na kraju rezultira malignom alternacijom i apoptozom stanica. Brojna istraživanja sugeriraju da je moguće djelovanjem na bihevioralne i psihološke čimbenike, utjecati na stanični imunosni odgovor stanica koje direktno utječu na rast i razvoj pojedinih tumora. ${ }^{5}$

Psihološki su čimbenici koji mogu utjecati na pojavu i tijek onkološke bolesti:

- stresni životni događaji - istraživanja uz ovaj faktor obično se vežu uz pojavu tumora dojke i elemente koji prethode pojavi bolesti

- socijalni odnosi i podrška okoline - studija koja je pratila 224 žene s karcinomom dojke u periodu od sedam godina pokazala je da je preživljavanje veće u žena koje su imale podršku obitelji i okoline

- čimbenici ličnosti - mnogi istraživači došli su do zaključka da je onkološkim bolesnicima zajednička teškoća u izražavanju emocija i potiskivanje depresivnoga raspoloženja, odnosno ti su ljudi otuđeni od samih sebe, a dobro prilagođeni drugima

- suočavanje s bolešću - osobe koje imaju aktivan stil suočavanja s tumorom imaju bolje šanse za preživljavanje

- negativne emocionalne reakcije - tjeskoba, tuga i depresivnost znatno utječu na ishod liječenja

- psihijatrijske bolesti - samo je jedna studija dokazala da je psihijatrijska bolest protektivni faktor za preživljavanje maligne bolesti, negativan odnos pokazale su četiri studije, a u pet nije zamijećena nikakva povezanost

- potiskivanje - što osoba više pokazuje emocije bolja je stopa preživljenja karcinoma. ${ }^{5}$
Mnoge nuspojave liječenja ostavljaju trajne posljedice na bolesnika, od promijenjene slike tijela do narušenog samopoštovanja, a znatan problem predstavlja i pojava psihijatrijskih bolesti koje često prate ovu fazu bolesti. Aktivna palijativna skrb posljednjih godina napravila je veliki iskorak iz bolničkih u ambulantne okvire, što se posebno očituje u kontroli simptoma u domu oboljelog te su na taj način osigurani psihosocijalni čimbenici koji osiguravaju bolju kvalitetu života, jer pomiču teret skrbi na obitelj i osiguravaju bolje odnose unutar obitelji uz pomoć educiranih savjetnika. ${ }^{4}$

\section{Psihijatrijski poremećaji kod onkoloških bolesnika}

Brojna istraživanja pokazala su da su psihijatrijski poremećaji kod onkoloških bolesnika učestaliji od ostalih tjelesnih simptoma. Faktori su koji utječu na pojavu psihijatrijskih poremećaja kod onkoloških bolesnika:

1. priroda bolesti

2. tijek liječenja

3. smanjen fertilitet

4. razni organski faktori

5. prijašnji stresori i psihijatrijski poremećaji

6. komunikacija s obitelji. ${ }^{6}$

Najčešće se javljaju depresivni poremećaji (o kojima će biti govora u idućem poglavlju), poremećaji prilagodbe i posttraumatski stresni poremećaj te ostali anksiozni poremećaji, seksualne disfunkcije, delirij i drugi kognitivni poremećaji. Anksiozni poremećaji javljaju se kao reakcija na karcinom, na čekanje rezultata testova probira, na tijek liječenja ili očekivanje povratka bolesti. Anksioznost povezana s karcinomom pojačava osjećaj boli, uzrokuje mučninu i povraćanje te negativno utječe na kvalitetu života bolesnika. Ako se ne liječi, znatno utječe na ishod liječenja i duljinu života bolesnika, jer potiskuju ili ignoriraju simptome povezane s karcinomom. Stopa potpuno razvijenih anksioznih poremećaja nije znatno veća od one u općoj populaciji. Bolesnici s karcinomom najčešće uočavaju da se intenzitet anksioznosti mijenja tijekom vremena te su često anksiozniji u slučajevima kada se karcinom počne širiti ili kad liječenje postane intenzivnije. ${ }^{7}$ Ponekad je teško razlikovati normalan strah od karcinoma od nenormalnih reakcija straha koje se klasificiraju u anksiozne poremećaje. Liječenje uvelike ovisi o tome koliko anksioznost utječe na svakodnevni život bolesnika. Bolesnike se od anksioznosti najčešće liječi psihoterapijom, sudjelovanjem u grupama samopomoći, hipnozom, tehnikama relaksa- 
cije te psihofarmacima. PTSP se definira kao odgođeni ili produljeni odgovor na stresni događaj ili situaciju iznimno jake ugroženosti koja može izazvati uznemirenost kod gotovo svake osobe. Iskustvo životno ugrožavajuće bolesti, poput karcinoma, također može dovesti do razvoja PTSP-a. ${ }^{7}$ Rezultati istraživanja pokazuju kako će otprilike $32 \%$ bolesnika s karcinomom razviti i PTSP. Rizični su faktori za razvoj PTSP-a nakon karcinoma bivše iskustvo stresnih životnih događaja, povijest psiholoških poteškoća, suočavanje putem izbjegavanja, loša socijalna podrška te loše tjelesno funkcioniranje. Disocijacija je jedan od načina odgovora na ekstremni stres, jer osoba ne procesuira u potpunosti strah ili ljutnju te obično nema razvijen zdrav način suočavanja sa stresom. Tip i ozbiljnost karcinoma ne utječu na to tko će kasnije razviti PTSP, već upravo iskustvo disocijacije u vrijeme dijagnoze karcinoma. Psihoza i delirij obično se javljaju u terminalnoj fazi bolesti. Delirij se obično događa iznenada, a simptomi osciliraju tijekom dana. Bolesnici doživljavaju konfuzno mentalno stanje i promjene u ponašanju te imaju problem s pozornošću, razmišljanjem, svjesnošću, emocijama, spavanjem i budnošću. ${ }^{7}$ Međutim, kognitivni poremećaji često nastaju i kao posljedica djelovanja karcinoma na organizam, uključujući otkazivanje organa, elektrolitnu neravnotežu, infekcije i nuspojave na liječenje. Rana identifikacija rizičnih faktora može pomoći u prevenciji nastupa delirija ili smanjiti vrijeme potrebno za korekciju stanja. Ako bolesnik nije opasan po sebe samoga, najčešće je dovoljno monitorirati simptome. U liječenju simptoma primjenjuju se i antipsihotici i sedativi, uz praćenje mogućih nuspojava. Odluka o davanju sedativa bolesniku u terminalnoj fazi karcinoma sa simptomima delirija postavlja brojna etička pitanja kako za liječnika tako i za obitelj, stoga je važan princip palijativne medicine sa stalnim provjerama stanja, uključivanjem obitelji i multidisciplinarnim pristupom u liječenju bolesnika.

\section{Depresija}

\section{Etiologija}

Depresija je najčešći psihijatrijski poremećaj koji je u ukupnoj populaciji prema učestalosti na četvrtom mjestu. Svjetska zdravstvena organizacija upozorava kako je incidencija depresija u velikom porastu te da broj oboljelih od depresije konstantno raste u svim zemljama svijeta.

Epidemiološka istraživanja navode kako oko $4 \%$ populacije boluje od težih, a $2 \%$ od blažih oblika depresije. Žene obolijevaju dva puta češće od muškaraca, što se obično povezuje s hormonskim promjenama.

Teorije o etiologiji depresije dijele se na dvije struje:

1. Biološke teorije pojavu depresije pripisuju neurokemijskim, neuroendokrinim i genskim promjenama u organizmu. Istraživanja Pariantea i njegovih suradnika dokazala su kako su povećano stanje upale $u$ organizmu i hiperreakcija osi hipotalamus - hipofiza - nadbubrežna žlijezda dvije najznačajnije biološke komponente koje su otkrivene kod bolesnika s depresijom. Genski su čimbenici, prema nekim istraživanjima, odgovorni za nastanak duševnih poremećaja u otprilike $70 \%$ slučajeva, no uz njih su potrebni i različiti okolišni čimbenici kako bi se bolest ispoljila. Od okolišnih čimbenika koji utječu na razvoj duševnih poremećaja najznačajniji je stres. Zahvaljujući navedenim otkrićima, može se zaključiti kako je razvoj duševnog poremećaja, prema biološkoj teoriji nastanka, posljedica nasljedne predispozicije i perzistirajuće citokinske upale u organizmu. Danas se kod bolesnika s otkrivenom citokinskom upalom primjenjuju terapijske intervencije u cilju smanjenja oštećenja neurona koji potencijalno dovode do nastanka bolesti.

2. Psihoanalitičke teorije osnovao je Sigmund Freud, koji je 1917. godine postavio tezu kako je depresija posljedica gubitka voljene osobe. $\mathrm{Na}$ suprot tome, socijalne teorije naglašavaju ulogu stresa pa se pretpostavilo kako niz stresnih životnih situacija predodređuje osobu za razvoj depresije, što nikad nije znanstveno dokazano. Neka istraživanja pokazala su kako su kod odraslih depresivnih bolesnika koji su pretrpjeli tešku psihičku traumu u djetinjstvu povišene razine CRP-a, bijelih krvnih stanica i fibrinogena, što navodi na zaključak kako je upalno stanje neka vrsta okidača za kasniji razvoj depresije. ${ }^{8}$

\section{Depresija kod onkoloških bolesnika}

Brojna znanstvena istraživanja bazirana su na objašnjenju moguće povezanosti psiholoških faktora, a osobito depresije, s razvojem i progresijom karcinoma. Postoje jasni dokazi o povezanosti karcinoma i depresije, s pojavnošću depresije kod solidnih tumora u postotku do 
$50 \% .{ }^{9}$ Osobito su osjetljivi bolesnici u uznapredovalom stadiju bolesti, kada u velikom broju imaju depresivne simptome, uz često prisutan delirij i intenzivnu bol. Oko $20 \%$ bolesnika s karcinomom ima ozbiljne depresivne poremećaje, a kod uznapredovalih je stadija i do $77 \%$ bolesnika depresivno. Depresija je povezana i sa slabijom kontrolom boli, lošijom suradljivošću i manjom željom za dugotrajnom terapijom, a simptomi mogu biti psihijatrijski poremećaj ili tjelesna posljedica samoga karcinoma ili liječenja. U procjeni i dijagnostici kliničke slike depresije najčešći su instrumenti za procjenu psihološkog distresa BSI (Brief Symptoms Inventory) i HADS (Hospital Anxiety and Depression Scale), koji su prilagođeni identificiranju simptoma u nepsihijatrijskom okružju. ${ }^{9}$ Također se primjenjuju i CES-D (Centre for Epidemiological Studies - Depression) ili BDI (Beck Depression Inventory). Pogrešno je ako liječnici poremećaj prilagodbe dožive kao prolazno stanje, iako stresori povezani s karcinomom traju dugo te se dijagnoza mora modificirati i ne smije se odgađati liječenje. Dakle, važno je istaknuti da u procjeni depresivne simptomatologije postoji visok rizik od njezina neprepoznavanja (depresivni simptom procjenjuje se kao normalna reakcija) ili pretjeranog dijagnosticiranja (procjena normalnih emocionalnih reakcija povezanih s karcinomom kao dijela depresije).

Kod onkoloških je bolesnika priroda depresije izrazito složena pa uvijek treba razmišljati o tome da su depresivni poremećaji ustvari sindromi, a ne bolesti te da uključuju razne poremećaje raspoloženja i različite kliničke slike.

Najčešći su simptomi velikoga depresivnog poremećaja:

- negativno raspoloženje

- osjećaj manjka energije

- loša koncentracija

- gubitak interesa

- poremećaj pamćenja

- manjak samopouzdanja

- osjećaj krivnje i beznađa

- smetnje spavanja i apetita. ${ }^{9}$

Obilježja tjelesne i psihičke anksioznosti i somatske pritužbe češća su u atipičnoj depresiji, a vrlo se često kod bolesnika vide simptomi razdražljivosti, ljutnje i agresivnosti. ${ }^{9}$ Slijedom navedenog, veliki broj liječnika smatra faktore kao što su progresija bolesti, cjelokupna ozbiljnost bolesti, socijalna podrška i prilagodba te otpornost na životne stresore, važnijima od samih kriterija u dijagnosticiranju depresije kod onkoloških bole- snika. U procjeni depresivne simptomatologije važno mjesto zauzima i umor, čija prevalencija iznosi 25 do 99 \% jer osjećaj umora može biti povezan i s liječenjem karcinoma i s depresijom.

Nekoliko je studija pokušalo utvrditi povezanost somatskih simptoma i depresije te se došlo do sljedećih rezultata:

- poremećaj spavanja i umor nisu bili značajno povezani s nesomatskim simptomima

- promjena apetita i smanjena sposobnost razmišljanja i koncentracije povezuje se s anhedonijom. ${ }^{9}$

Ove su povezanosti bile konzistentne nakon prilagodbe na tjelesno funkcioniranje i bol, a samo su bolesnici s promjenama apetita pokazali veću ozbiljnost depresije. Rezultati dakle ukazuju kako se individualni somatski simptomi razlikuju po prirodi te se simptomi poput promjena apetita i smanjene sposobnosti razmišljanja upotrebljavaju kao važni u dijagnozi depresije u onkoloških bolesnika, dok poremećaj spavanja i umor nisu u tome korisni.

Sama dijagnoza i razvoj karcinoma izrazito su stresna iskustva, a karcinomi većinom postaju kronična stanja koja dovode do prolongiranoga stresa s promjenama ponašanja i znatnih imunosnih promjena. Periferne imunosne stanice proizvode protuupalne citokine, odnosno signale koji signaliziraju mozgu da promijeni prioritete organizma u suočavanju s prijetnjom. Takva reorganizacija prioriteta rezultira promjenama na subjektivnoj, spoznajnoj i psihološkoj razini. Kod onkoloških bolesnika mnogo su češće pasivne suicidalne misli od prave suicidalnosti iako i ona može biti prisutna kod bolesnika koji nisu suradljivi i odbijaju liječenje. Neka istraživanja pokazala su da psihološki status utječe na dužinu preživljenja kod nekih tipova karcinoma, npr. melanoma, karcinoma pluća, dojke i bubrega, te se ispostavilo kako je ovaj utjecaj prisutan i deset godina nakon dijagnoze. $U$ istraživanju provedenom na 1000 bolesnika s osmogodišnjim praćenjem pokazalo se kako je zajednička prisutnost karcinoma i depresije bila povezana s povećanim rizikom za smrt. ${ }^{9}$ Utjecaj depresije na mortalitet onkoloških bolesnika još uvijek nije u potpunosti potvrđen, iako se depresija povezuje s bržom progresijom bolesti. Mogući su razlozi za to smanjena suradljivost u liječenju, neuroimunološke promjene, promjena ponašanja i utjecaj depresije na društveno, radno i obiteljsko funkcioniranje. Ono što je izrazito važno u liječenju onkoloških bolesnika jest činjenica da se depresivni poremećaj ne smije smatrati normalnim pratiteljem karcinoma ili poremećajem koji se ne može liječiti. Iz navedenog je razloga izrazito važna stalna edukacija onkologa, uz važnu ulogu 
psihijatra koji će primjenjivati farmakoterapijske i psihoterapijske intervencije u cilju liječenja depresije. Lijekovi s najmanje nuspojava koji se primjenjuju za kontrolu anksioznosti jesu anksiolitici te su zbog svojih povoljnih utjecaja na bolesnika u najširoj primjeni.

Psihoterapijski pristup liječenja onkoloških bolesnika sastoji se i od terapijskog rada s bolesnikom od postavljanja dijagnoze do završetka liječenja. Čimbenici su koji utječu na formiranje psihoterapijskog pristupa u radu s onkološkim bolesnicima:

- karakteristike osobnosti bolesnika

- razlozi za psihijatrijsku intervenciju

- bolesnikov doživljaj aktualne bolesti

- identifikacija životnih situacija koje su potencijalno utjecale na razvoj duševnog poremećaja

- bolesnikove metode koje primjenjuje kako bi ublažio stres

- obrazac ponašanja kojim se koristio u prošlosti, a potencijalno je uzrokovao sadašnju situaciju..$^{10}$

Ciljevi psihoterapijskog rada s bolesnikom bazirani su na otklanjanju situacija koje znatno utječu na tijek liječenja, na smanjenju otpora liječenju te edukaciji bolesnika kako prihvatiti bolest i motivirati se za daljnje terapijske postupke.

Kod liječenja bolesnika na onkološkom odjelu razlikuje se pet različitih terapijskih postupaka:

1. informativno-edukacijski sastanci bolesnika osiguravaju bolesnicima mogućnost da otvoreno govore o svojim simptomima, psihoterapeut kroz odgovarajuća pitanja razjašnjava bolesniku trenutni klinički status te pojašnjava simptome i strahove s kojima se bolesnik suočava

2. individualne psihoterapijske intervencije - sastoje se od strpljivog slušanja bolesnika, uvažavanja njegovih tegoba i kontinuiranog praćenja odnosa bolesnik-liječnik i obratno

3. grupna psihoterapija - važna je na samom početku dijagnostike karcinomske bolesti jer omogućuje bolesniku verbalizaciju simptoma, što posljedično dovodi do spoznaje da i drugi bolesnici proživljavaju slično te smanjuje osjećaj izoliranosti i usamljenosti kod bolesnika

4. konzultacije psihijatra i onkologa - imaju za cilj ukazivanje na one bolesnike koji imaju psihološke poteškoće u prihvaćanju bolesti, a sam zadatak rada s osobljem utječe na identifikaciju negativnih osjećaja i mogućnost njihova svladavanja
5. rad s obitelji - uključivanje obitelji u terapijske postupke onkološkog bolesnika pomaže u prevladavanju anksioznosti te jača unutarnju sigurnost obitelji koja je poremećena spoznajom o onkološkoj bolesti jednoga člana. ${ }^{10}$

Biološko-medicinski aspekti liječenja malignih bolesti na prvom su mjestu u nadležnosti onkologa, dok je psihijatar zadužen za zbrinjavanje psiholoških problema i kreiranje programa zdravstveno-odgojnih aktivnosti. Onkološki bolesnici moraju se prilagoditi suživotu s bolešću, što izaziva različite reakcije kod ljudi, stoga je važno na vrijeme prepoznati kojem je bolesniku potrebna psihoterapijska pomoć te mu je omogućiti.

\section{Uloga medicinske sestre u liječenju onkoloških bolesnika}

Medicinske sestre pružaju pomoć onkološkim bolesnicima i njihovim obiteljima kroz razne edukativne aktivnosti. Sestrinske intervencije nužne su u svim fazama bolesti. Medicinska sestra uvodi bolesnika u terapijski postupak, educira ga u smislu zdravstvene njege, prva će uočiti nove simptome ili pogoršanje bolesti te je dužna o navedenome obavijestiti liječnika.

Kako bi na pravilan način zbrinula bolesnika, medicinska sestra mora procijeniti njegovo tjelesno stanje primjenjujući KPS ili ECOG skalu, koje daju podatke o nivou funkcionalne sposobnosti bolesnika. ${ }^{11} \mathrm{~S}$ obzirom na zahtjevnost posla u zbrinjavanju onkološkog bolesnika, medicinska sestra mora biti visoko stručna, imati visok stupanj empatije za bolesnika i njegovu obitelj te visoke moralne kvalitete.

Nakon uvida u bolesnikovo stanje, medicinska sestra postavlja sestrinsku dijagnozu, koja se kod onkoloških bolesnika najčešće odnosi na poremećaje prehrane, povišene rizike za infekciju, oštećenje sluznica te razvoj anksiozno-depresivnog poremećaja.

Onkološkim bolesnicima izrazito je važno omogućiti sudjelovanje u raznim aktivnostima ovisno o njihovim mogućnostima i željama. Napretkom maligne bolesti dolazi do mogućeg razvoja depresije i anksioznosti, stoga je medicinska sestra dužna poticati bolesnika na razgovor, razgovarati s bolesnikom o vedrim temama te poticati bolesnika na razgovor s ostalim bolesnicima.

U slučajevima kad se kod onkoloških bolesnika javlja strah od ishoda bolesti, medicinska sestra prikupit će podatke o čimbenicima koji uzrokuju strah, o načinima suočavanja sa stresom te tjelesnim manifestacijama straha kod bolesnika. 
S obzirom na to je bol kod onkoloških bolesnika kronična, medicinska sestra dužna je prikupiti podatke o širenju, trajanju i lokalizaciji boli, o utjecaju kronične boli na socijalni život bolesnika te podatke o dotadašnjim načinima ublažavanja boli.

Zdravstvena njega onkoloških bolesnika s pridruženim duševnim poremećajem iznimno je zahtjevna za medicinsku sestru, jer osim znanja mora imati i razvijene komunikacijske vještine. Uspjeh zdravstvene njege u ovom slučaju ovisi o sposobnosti medicinske sestre na prilagodbu različitih zahtjeva i funkcija njezine uloge u dobrobiti bolesnika, kao i otvorenosti za osjećaje i strahove bolesnika. Medicinska sestra dužna je poticati bolesnika na izražavanje misli, osjećaja i očekivanja te ga poticati na aktivno sudjelovanje u liječenju.

\section{Cilj istraživanja}

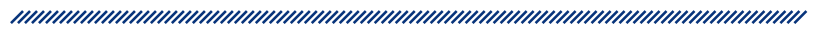

Cilj je istraživanja procijeniti kliničku sliku depresije kod onkoloških bolesnika na temelju upitnika za test depresije (Beck Depression Inventory) ${ }^{12}$. Istraživanje je provedeno na internom odjelu Opće bolnice Šibenik u onkološkoj ambulanti na uzorku od 50 ispitanika.

Rezultati istraživanja statistički su obrađeni te su prikazani tablično i grafički, ovisno o ispitivanim parametrima.

\section{Materijal i metode}

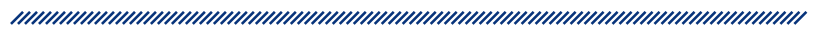

ispitanici uključeni u ovo istraživanje onkološki su bolesnici liječeni na internom odjelu u onkološkoj ambulanti Opće bolnice Šibenik. Svaki ispitanik prije uključivanja upoznat je s ciljevima i postupcima u okviru istraživanja te je dobrovoljno pristao na test. $U$ ispitivanju je sudjelovalo 37 žena i 13 muškaraca. Za potrebe istraživanja primijenjen je Beckov test depresije koji se sastoji od 21 pitanja, a na svako je moguće odgovoriti s četiri odgovora koji se ocjenjuju od 0 do 3.

Testom se ispituje poremećaj raspoloženja, gubitak nade, osjećaj odbačenosti i krivice, nesposobnost za uživanje, potreba za kažnjavanjem i mržnja prema sebi.

Minimalan je rezultat testa nula, a maksimalan 63.

\section{Rezultati istraživanja}

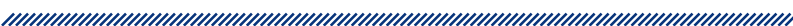

Na samom početku prikazat će se podjela ispitanika koji su sudjelovali u istraživanju prema spolu i dobi. Rezultat je grafički prikazan na slici 1 .

Na slici 1 vidljivo je kako je najveći broj onkoloških bolesnika koji su sudjelovali u istraživanju u dobi od 30 do 40 godina. Većinu ispitanika čine žene, točnije 37 . U istraživanju je sudjelovalo i 13 muškaraca.

Najmanje je bolesnika u dobnoj skupini od 61 do 80 godina, ukupno 13.

Idući rezultat prikazat će ispitivane parametre prema Beckovu testu depresije. Rezultati su prikazani u tablici 1.

Tablica 1. Beck Depression Inventory

\begin{tabular}{|l|c|c|c|c|c|}
\hline & 0 & 1 & 2 & 3 & Prosjek \\
\hline Hipohondrija & 50 & 0 & 0 & 0 & 0,00 \\
\hline Gubitak nade & 0 & 50 & 0 & 0 & 0,00 \\
\hline $\begin{array}{l}\text { Mržnja prema } \\
\text { samome sebi }\end{array}$ & 50 & 0 & 0 & 0 & 0,00 \\
\hline Osjećaj krivice & 42 & 8 & 0 & 0 & 0,19 \\
\hline Osjećaj odbačenosti & 45 & 5 & 0 & 0 & 0,11 \\
\hline Samoosuđivanje & 50 & 0 & 0 & 0 & 0,00 \\
\hline Potreba za kaznom & 50 & 0 & 0 & 0 & 0,00 \\
\hline Negativna slika o sebi & 39 & 11 & 0 & 0 & 0,28 \\
\hline $\begin{array}{l}\text { Nesposobnost } \\
\text { uživanja }\end{array}$ & 50 & 0 & 0 & 0 & 0,00 \\
\hline Nesposobnost za rad & 50 & 0 & 0 & 0 & 0,00 \\
\hline Gubitak na težini & 0 & 35 & 15 & 0 & 0,42 \\
\hline $\begin{array}{l}\text { Poremećaj u odnosu } \\
\text { s drugima }\end{array}$ & 39 & 11 & 0 & 0 & 0,28 \\
\hline Poremećaj sna & 50 & 0 & 0 & 0 & 0,00 \\
\hline $\begin{array}{l}\text { Sklonost } \\
\text { samoubojstvu }\end{array}$ & 50 & 0 & 0 & 0 & 0,00 \\
\hline $\begin{array}{l}\text { Poremećaj } \\
\text { raspoloženja }\end{array}$ & 0 & 50 & 0 & 0 & 0,00 \\
\hline Plačljivost & 39 & 11 & 0 & 0 & 0,28 \\
\hline Razdražljivost & 50 & 0 & 0 & 0 & 0,00 \\
\hline Neodlučnost & 39 & 11 & 0 & 0 & 0,28 \\
\hline Umor & 0 & 35 & 15 & 0 & 0,42 \\
\hline Gubitak apetita & & & & \\
\hline Oslabljeni libido & & & & \\
\hline
\end{tabular}




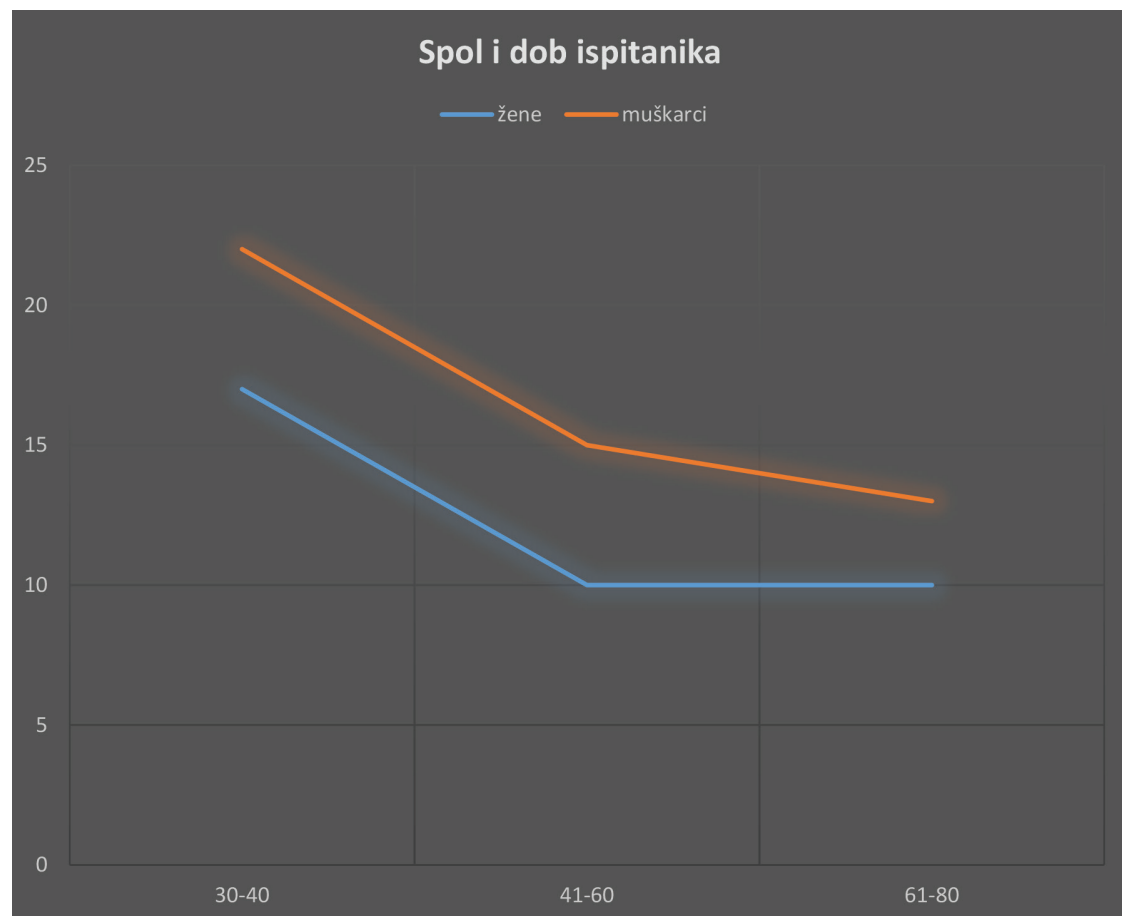

Slika 1. Prikaz ispitanika prema dobi i spolu

Iz tablice 1 može se zaključiti kako je razvoj blage depresivnosti iskazan u pitanjima koja se odnose na poremećaje u odnosu s drugima, negativnu sliku o samome sebi, gubitak na kilaži, osjećaj krivice i odbačenosti, razdražljivost, umor, gubitak apetita i oslabljeni libido. Svi ostali ispitivani parametri pokazuju najmanje prosječne vrijednosti.

Rezultati tablice 2 prema ispitivanim parametrima ukazuju na to kako je razvoj blage depresije kod žena iskazan kroz pitanja o gubitku težine, negativnoj slici o sebi, gubitku apetita te osjećaju krivice.

Iz tablice 3 može se zaključiti kako je najveći postotak u razvoju blage depresije kod muškaraca iskazan u pitanju poremećaja odnosa s drugim ljudima, slijede gubitak na težini, osjećaj krivice i odbačenosti, smanjen libido, razdražljivost, umor i gubitak apetita.

Navedeni rezultati prikazat će se i grafički prema spolu ispitanika i odgovorima koji ukazuju na razvoj blage depresivnosti.

Iz slike 2 može se zaključiti kako je veći broj ispitanika ženskog spola koji imaju negativnu sliku o sebi, što se često povezuje s promjenom težine $i$ vanjskog izgleda bolesnica. Onkološki bolesnici često se žale na činjenicu da im se fizički izgled drastično promijenio nakon kemoterapija pa to često dovodi do razvoja blage de-

\begin{tabular}{|c|c|c|c|c|c|}
\hline & 0 & 1 & 2 & 3 & Prosjek \\
\hline Hipohondrija & 37 & 0 & 0 & 0 & 0,00 \\
\hline Gubitak nade & 0 & 37 & 0 & 0 & 0,00 \\
\hline Mržnja prema samome sebi & 37 & 0 & 0 & 0 & 0,00 \\
\hline Osjećaj krivice & 32 & 5 & 0 & 0 & 0,16 \\
\hline Osjećaj odbačenosti & 34 & 3 & 0 & 0 & 0,08 \\
\hline Samoosuđivanje & 37 & 0 & 0 & 0 & 0,00 \\
\hline Potreba za kaznom & 37 & 0 & 0 & 0 & 0,00 \\
\hline Negativna slika o sebi & 27 & 10 & 0 & 0 & 0,37 \\
\hline Nesposobnost uživanja & 37 & 0 & 0 & 0 & 0,00 \\
\hline Nesposobnost za rad & 37 & 0 & 0 & 0 & 0,00 \\
\hline Gubitak na težini & 0 & 25 & 12 & 0 & 0,48 \\
\hline Poremećaj u odnosu s drugima & 37 & 0 & 0 & 0 & 0,00 \\
\hline Poremećaj sna & 37 & 0 & 0 & 0 & 0,00 \\
\hline Sklonost samoubojstvu & 37 & 0 & 0 & 0 & 0,00 \\
\hline Poremećaj raspoloženja & 0 & 37 & 0 & 0 & 0,00 \\
\hline Plačljivost & 0 & 37 & 0 & 0 & 0,00 \\
\hline Razdražljivost & 37 & 0 & 0 & 0 & 0,00 \\
\hline Neodlučnost & 37 & 0 & 0 & 0 & 0,00 \\
\hline Umor & 37 & 0 & 0 & 0 & 0,00 \\
\hline Gubitak apetita & 0 & 25 & 12 & 0 & 0,48 \\
\hline Oslabljeni libido & 37 & 0 & 0 & 0 & 0,00 \\
\hline
\end{tabular}




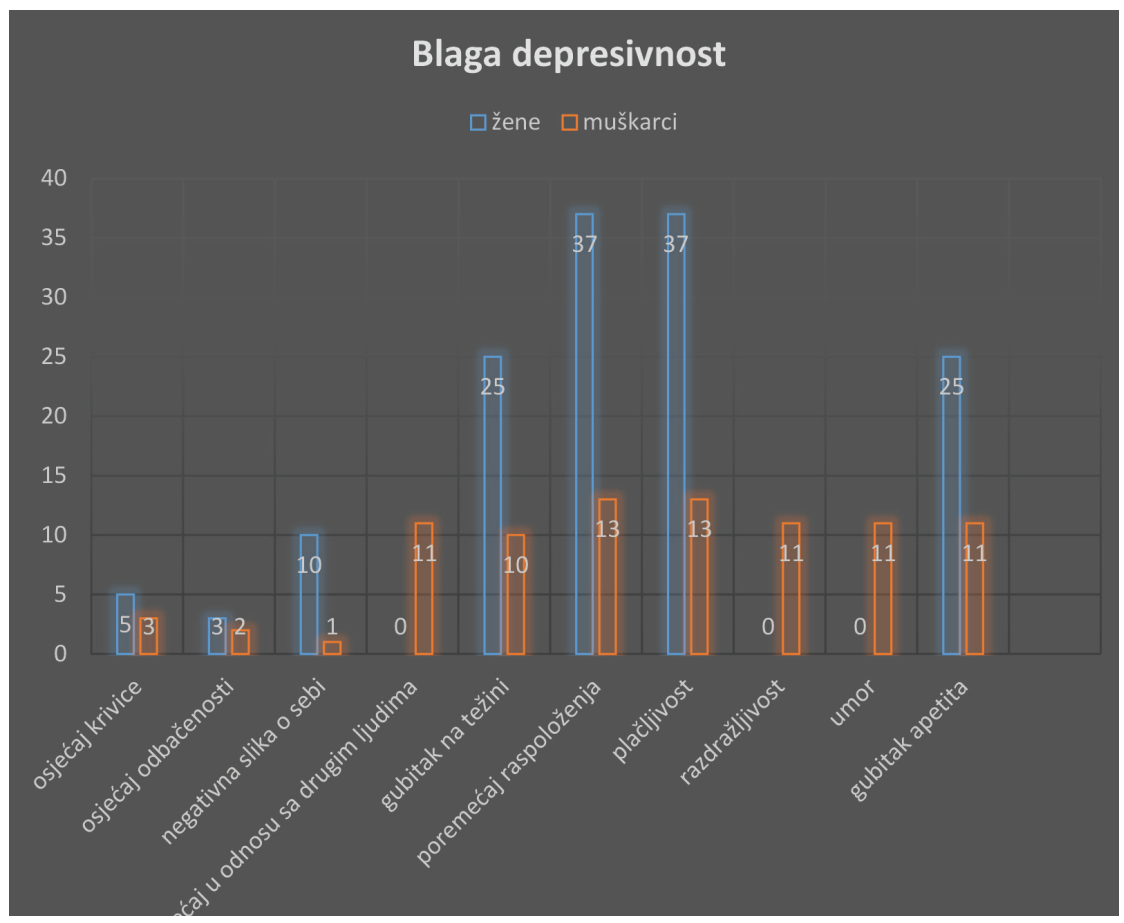

Slika 2. Blaga depresivnost

Tablica 3. Rezultati testa kod muških ispitanika

\begin{tabular}{|c|c|c|c|c|c|}
\hline & 0 & 1 & 2 & 3 & Prosjek \\
\hline Hipohondrija & 13 & 0 & 0 & 0 & 0,00 \\
\hline Gubitak nade & 0 & 13 & 0 & 0 & 0,00 \\
\hline Mržnja prema samome sebi & 13 & 0 & 0 & 0 & 0,00 \\
\hline Osjećaj krivice & 10 & 3 & 0 & 0 & 0,30 \\
\hline Osjećaj odbačenosti & 11 & 2 & 0 & 0 & 0,18 \\
\hline Samoosuđivanje & 13 & 0 & 0 & 0 & 0,00 \\
\hline Potreba za kaznom & 13 & 0 & 0 & 0 & 0,00 \\
\hline Negativna slika o sebi & 10 & 1 & 0 & 0 & 0,10 \\
\hline Nesposobnost uživanja & 13 & 0 & 0 & 0 & 0,00 \\
\hline Nesposobnost za rad & 13 & 0 & 0 & 0 & 0,00 \\
\hline Gubitak na težini & 0 & 10 & 3 & 0 & 0,30 \\
\hline Poremećaj u odnosu s drugima & 2 & 11 & 0 & 0 & 0,55 \\
\hline Poremećaj sna & 13 & 0 & 0 & 0 & 0,00 \\
\hline Sklonost samoubojstvu & 13 & 0 & 0 & 0 & 0,00 \\
\hline Poremećaj raspoloženja & 0 & 13 & 0 & 0 & 0,00 \\
\hline Plačljivost & 0 & 13 & 0 & 0 & 0,00 \\
\hline Razdražljivost & 2 & 11 & 0 & 0 & 0,55 \\
\hline Neodlučnost & 13 & 0 & 0 & 0 & 0,00 \\
\hline Umor & 2 & 11 & 0 & 0 & 0,55 \\
\hline Gubitak apetita & 0 & 10 & 3 & 0 & 0,30 \\
\hline Oslabljeni libido & 11 & 2 & 0 & 0 & 0,18 \\
\hline
\end{tabular}

presije. Parametri poput osjećaja krivice i osjećaja odbačenosti pokazuju niže rezultate u obje skupine ispitanika pa su samim time $u$ analizi manje značajni.

Za razliku od ženskih ispitanika, muški su na pitanja poremećaja odnosa s drugim ljudima, razdražljivosti i umora odgovarali potvrdno, što se vjerojatno odnosi na činjenicu kako od brige za vlastito zdravlje nemaju vremena razmišljati o drugim ljudima te im to izaziva razdražljivost i umara ih.

U kategorijama poremećaja raspoloženja, plačljivosti i gubitka na težini svi su ispitanici odgovarali potvrdno.

\begin{tabular}{|c|c|c|}
\hline Rezultat & Frekvencija & Postotak \\
\hline Odsutnost depresije $(0-11)$ & 27 & $73 \%$ \\
\hline Blaga depresija (12 - 19) & 8 & $22 \%$ \\
\hline Umjerena depresija (20 - 26) & 2 & $5 \%$ \\
\hline Teška depresija (više od 26) & 0 & $0 \%$ \\
\hline
\end{tabular}

Na temelju dobivenih vrijednosti može se zaključiti kako prema Beckovu inventaru depresije većina ženskih ispitanika nema oscilacije u raspoloženju, točnije $73 \%$. Nešto viši rezultat na skali $12-19$, odnosno $22 \%$, ukazuje na blage promjene raspoloženja. Manji postotak 
(5\%) čine ispitanice s umjereno izraženom depresijom. Tešku depresivnost nije pokazala nijedna ispitanica.

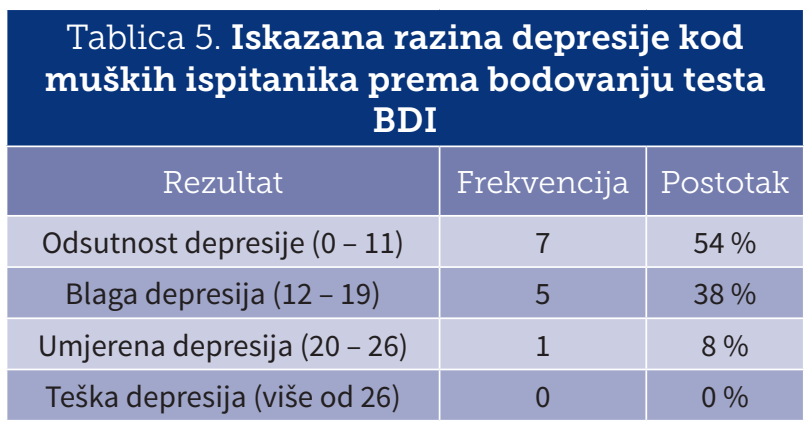

Na temelju dobivenih vrijednosti može se zaključiti kako prema Beckovu inventaru depresije većina muških ispitanika nema oscilacije u raspoloženju, točnije $54 \%$. Nešto viši rezultat na skali 12 - 19, odnosno $38 \%$, ukazuje na blage promjene raspoloženja. Manji postotak $(8 \%)$ čine ispitanici s umjereno izraženom depresijom. Tešku depresivnost nije pokazao nijedan ispitanik.

\begin{tabular}{|c|c|c|c|}
\hline \multicolumn{4}{|c|}{ Tablica 6. Učestalost i pojavnost depresije } \\
ovisno o spolu ispitanika
\end{tabular}

Iz tablice 6 vidljivo je kako je blaga depresija utvrđena u $38 \%$ muških ispitanika ovisno o odgovorima na testu, u odnosu na žene gdje taj postotak iznosi $22 \%$. Prema provedenom istraživanju, ukupna pojavnost depresije kod onkoloških bolesnika iznosi $26 \%$ iako je u fazi blagog razvoja. Umjerenu depresiju, od ukupnog broja ispitanika, razvilo ih je $6 \%$.

Rezultati iz tablice prikazani su i grafički na slici 3.

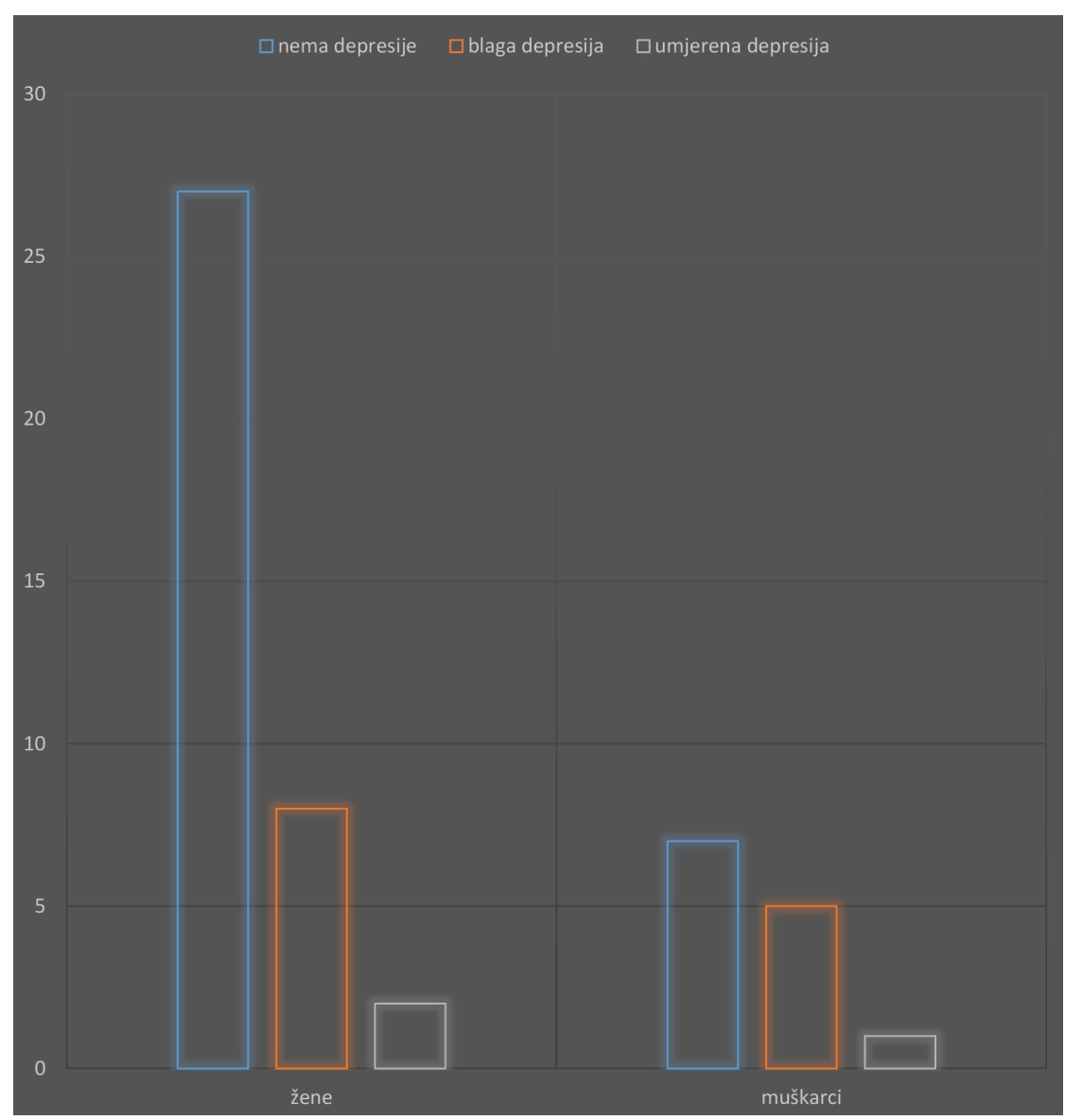

Slika 3. Pojavnost i učestalost depresije ovisno o spolu 


\section{Rasprava}

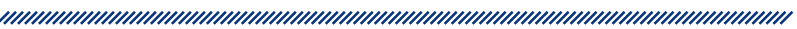

Rezultati istraživanja pokazali su kako je kod ispitivanih bolesnika, prema odgovorima na test, blaga depresija utvrđena u $38 \%$ muških ispitanika, u odnosu na žene gdje taj postotak iznosi $22 \%$. Ukupna pojavnost depresije kod onkoloških bolesnika, prema provedenom istraživanju, iznosi $26 \%$ iako je u fazi blagog razvoja. Od ukupnog broja ispitanika, umjerenu depresiju razvilo ih je $6 \%$. Razvoj blage depresivnosti iskazan je u pitanjima koja se odnose na poremećaje u odnosu s drugima, negativnoj slici o samome sebi, gubitku na kilaži, osjećaju krivice i odbačenosti, razdražljivosti, umoru, gubitku apetita i oslabljenom libidu. Svi ostali ispitivani parametri pokazuju najmanje prosječne vrijednosti. Veći broj ispitanika ženskog spola izjavio je kako imaju negativnu sliku o sebi, što se često povezuje s promjenama težine i vanjskog izgleda bolesnica. Onkološki bolesnici često se žale na činjenicu da im se fizički izgled drastično promijenio nakon kemoterapija pa to često dovodi do razvoja blage depresije. Veći broj muških ispitanika također je na pitanje o gubitku težine označio kako se težina smanjila u odnosu na prije. Za razliku od ženskih ispitanika, muški su na pitanje o odnosu s drugim ljudima odgovorili da se promijenio, što se odnosi na činjenicu kako od brige za vlastito zdravlje nemaju vremena razmišljati o drugim ljudima.

U kategorijama poremećaja raspoloženja, plačljivosti i gubitka na težini svi su ispitanici odgovarali potvrdno. Na temelju dobivenih vrijednosti može se zaključiti kako prema Beckovu inventaru depresije većina ženskih ispitanika nema oscilacije u raspoloženju, točnije $73 \%$. Nešto viši rezultat na skali 12 - 19, odnosno $22 \%$, ukazuje na blage promjene raspoloženja. Manji postotak (5\%) čine ispitanice s umjereno izraženom depresijom. Tešku depresivnost nije pokazala nijedna ispitanica. Kad je riječ o muškim ispitanicima, može se zaključiti kako prema Beckovu inventaru depresije većina ispitanika nema oscilacije u raspoloženju, točnije $54 \%$. Nešto viši rezultat na skali 12 - 19, odnosno $38 \%$, ukazuje na blage promjene raspoloženja. Manji postotak (8 \%) čine ispitanici s umjereno izraženom depresijom. Tešku depresivnost nije pokazao nijedan ispitanik. Može se zaključiti kako se rezultati ovog istraživanja o razvoju depresije kod onkoloških bolesnika preklapaju s dosadašnjim istraživanjima na istu temu, iako ovo istraživanje nije dalo statistički značajne razlike razvoja depresije u odnosu na spol ispitanika. S obzirom na to da je istraživanje provedeno na malom uzorku ispitanika, može se zaključiti da bi rezultati bili drugačiji da je sudjelovalo više ljudi s različitim fazama karcinomske bolesti te da ovo istraživanje otvara mogućnost za dodatna ispitivanja na većem uzorku. Kako bi se bolje pojasnio problem javljanja depresivno-anksioznih poremećaja kod onkoloških bolesnika, spomenut će se neka dosadašnja istraživanja na istu temu. Istraživanje koje su provodili Vukojević i suradnici na odjelu onkologije Sveučilišne kliničke bolnice u Mostaru obuhvatilo je 160 ispitanika koji su bili podijeljeni u dvije skupine; ispitnu i kontrolnu. Svakom bolesniku iz ispitne skupine pridružen je bolesnik iz kontrolne skupine prema dobi, stupnju obrazovanja i bračnom statusu. Ispitna skupina liječila se u Sveučilišnoj kliničkoj bolnici u Mostaru, a kontrolna u ordinaciji obiteljske medicine Doma zdravlja Mostar. Ispitna je skupina pokazala statistički viši stupanj depresivnosti u odnosu na kontrolnu skupinu, dok za anksioznost nije utvrđena statistički značajna razlika. Na Zavodu za onkologiju i radioterapiju Kliničkog bolničkog centra u Splitu ispitivana je učestalost depresije među onkološkim bolesnicama koje boluju od karcinoma dojke. Rezultati istraživanja pokazali su znatno veću učestalost pojavnosti depresije u cijeloj skupini ispitanica oboljelih od karcinoma dojke u odnosu na pojavnost depresije kod žena u općoj populaciji. Rezultati istraživanja pokazali su kako je u ukupnom postotku najčešća blaga depresija. lako su rezultati pokazali da je učestalost depresije veća kod žena koje su na kemoterapiji, razlika nije bila statistički značajna pa se povećani udio depresije kod žena na kemoterapiji ipak nije uspio dokazati. Na Zavodu za torakalnu, plastičnu i rekonstrukcijsku kirurgiju u Kliničkom bolničkom centru Osijek provedeno je istraživanje o utjecaju operacijskog zahvata na sliku žena s karcinomom dojke o samima sebi. $U$ ispitivanju su sudjelovale 354 žene, od kojih je 176 bilo zdravo, a 178 na liječenju. Bolesnice s nižom razinom socijalne podrške imale su lošiju sliku o sebi te više razine depresije, anksioznosti i stresa u odnosu na žene koje su imale snažnu socijalnu podršku. U Psihoonkološkom savjetovalištu Opće bolnice Pula provedeno je istraživanje o razlici razine depresije kod onkoloških bolesnika koji su sudjelovali u psihoonkološkoj terapiji u odnosu na one koji nisu pristupili tretmanu. T-testom za velike ovisne uzorke utvrđeno je da postoji statistički značajna razlika u anksioznosti i depresivnosti ispitanika prije i poslije terapije. Ispitanici su pokazali znatno nižu razinu depresivnosti nakon šest mjeseci terapije. Prema navedenim istraživanjima može se zaključiti kako su žene postizale znatno viši rezultat na skali depresivnosti, što se dijelom pokazalo i u 
ovom istraživanju kod pitanja doživljavanja sebe nakon gubitka tjelesne težine. Nije bilo statistički značajnih razlika u stupnju depresivnosti prema skupinama, ali su bolesnici na kemoterapiji pokazali znatno viši rezultat na skali anksioznosti. Korelacija stupnja anksioznosti i depresije nije bila izvediva jer je liječenje obilježeno samo za dio ispitanika pa je obrađena povezanost s brojem hospitalizacija koja nije pokazala znatne razlike među skupinama. Navedena istraživanja, uključujući i ovo, do sad nisu uspjela statistički dokazati da se razina depresije povećava ovisno o fazi progresije karcinomske bolesti.

\section{Zaključak}

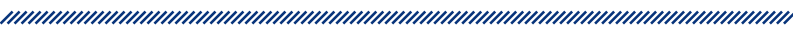

Već je prvi susret s dijagnozom maligne bolesti dovoljan razlog straha kod bolesnika, u odnosu na susret s bilo kojom drugom bolešću. Prva je reakcija bolesnika na dijagnozu karcinoma upravo strah, odnosno strah od smrti i odvajanja od dragih ljudi iz okoline. S obzirom na izrazito visoku stopu smrtnosti od malignih bolesti, ne iznenađuje činjenica da ovi bolesnici prolaze kroz različita duševna stanja. Onkološki bolesnici suočeni su i s nizom mogućih psiholoških problema, kao i onih na duhovnoj razini. Svi se ovi faktori mijenjaju ovisno o tijeku bolesti, ali je zabrinutost za vlastitu budućnost uvijek prisutna.

\section{Referencije}

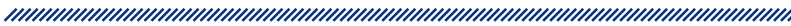

1. Gregurek R, Braš M. Psihoonkologija, Grafika Osijek, Osijek, 2008.

2. American Psychiatric Association. Diagnostic and statistical manual of mental disorders. $4^{\text {th }}$ edition, Washington DC: APA, 1994.

3. Berard RMF. Depression and anxiety in oncology: The Psychiatrists perspective, J Clin Psychiatry, 2001.

4. Mihaljević-Peleš A, Šagud M. Psihofarmakoterapijske intervencije u onkologiji, u Psihoonkologija, Grafika Osijek, Osijek, 2008.

5. Gregurek R. Maligne bolesti (onkologija), u: Suradna i konzultativna psihijatrija, Školska knjiga, Zagreb, 2006.

6. Greenwald P. Cancer prevention clinical trials, J Clin Oncol 20 (suppl 18), 2002.

7. Stein CJ, Colditz GA. Modifiable risk factors for cancer, $\mathrm{Br}$ J Cancer 90, 2004.

8. American Academy od Pain Medicine, https://www.ampainsoc.org/

9. Jakovljević M. Depresivni poremećaji: od radnog prepoznavanja do uspješnog liječenja, Zagreb, Pro Mente, 2003.

10. Hotujac Lj i sur. Psihijatrija, Zagreb, Medicinska naklada, Zagreb, 2006.

11. Prlić N, Rogina V, Muk B. Zdravstvena njega 4: zdravstvena njega kirurških, onkoloških i psihijatrijskih bolesnika, Školska knjiga, Zagreb, 2005.

12. Beck A.T., Steer R.A., Brown G.K. BDI-II - Beckov upitnik depresije,2. izdanje-hrvatska verzija, Naklada Slap, Jastrebarsko,2008. 


\section{DEPRESSION IN CANCER PATIENTS}

1 Marina Cigić

2 Josipa Rožman

1 Department of Internal Medicine - Oncology Clinic, General Hospital Šibenik

2 Department of Psychiatry, General Hospital Kalovac

\section{Summary}

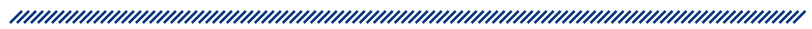

Depression is the most common psychiatric disorder, ranking fourth in the overall population. People who face death go through various mental states and phases, such as anger, bargaining, depression, and acceptance; and the most common defenses used by a cancer patient are regression, denial, projection, and repression. Research has shown that psychiatric disorders are as common, if not more so, as other physical symptoms in cancer patients.

The aim of this study was to assess the clinical picture of depression in oncology patients based on the Beck Depression Inventory (BDI) questionnaire. The study was conducted at the Department of Internal Medicine of the General Hospital Šibenik in the oncology clinic, on a sample of 50 people.

The results of the research showed that no severe form of depression was found among the respondents and according to the BDI questionnaire, the percentage which it appeared in it showed cases of mild depression.

Keywords: depression, oncology patients, BDI 